\title{
MATHEMATICAL FORMULATION OF THE PROCESS OF SUSPENSIONS FILTRATION THROUGH FLAT POROUS PARTITIONS
}

\author{
Vladimir Viktorovich Bredihin ${ }^{1 \star}$ Alexander Anatolyevich Akulshin ${ }^{1}$ Natalia Vladimirovna Bredihina ${ }^{1}$ \\ ${ }^{1}$ Southwest State University, Kursk, Russia
}

This paper presents the mathematical formulation of the process of filtering suspensions being formed as a result of semiconductor products manufacturing from gallium arsenide, using flat porous partitions. To develop the methods of production units calculation, there has been conducted an analysis of data found in the literature and the obtained dependencies.

Key words: Filtration rates, Gallium arsenide, Precipitations, Porous partitions, Filtration

\section{INTRODUCTION}

The methods of making semiconductor devices are very diverse. However, in all cases in the production process, semiconductor products are subject to a number of general basic processing steps. Technological process includes the step of water control of semiconductor materials' components; the step of semiconductor materials manufacturing and their mechanical and chemical processing; the step of epitaxial deposition of semiconductor layer; obtaining a protective dielectric film; photolithographic processing of this film; ion-implantation process and diffusion of an impurity to obtain the active and passive regions of the structure; application of non-rectifying contacts and making thin-film passive components-resistors and capacitors; separating plates into crystals; assembling and encapsulating devices; measuring electrical parameters and testing devices [02-08].

Mechanical treatment in the manufacture of semiconductor devices lies in obtaining the work pieces of required sizes, shapes with a required surface quality by cutting ingots into wafers, grinding and polishing of wafers by different mechanical and mechanochemical methods [02-07]

Cutting process produces a lot of heat. Cooling fluid is fed to cutting area. Liquid flow rate is $1.5-2 \mathrm{l} / \mathrm{min}$. per cutter $[01,02,07]$. Running water or special emulsions of complex composition performing the functions of anti-friction fluid and facilitating the collection of processed material waste are used for cooling the place of cutting [02, 05, 07-12].

The wastewater generated in the process of cutting semiconductor wafers contains the amount of suspended material up to $45 \%$ of the original product. The degree of dispersion depends on the type of cutting, cutting speed and thickness of the cutting wheel. The concentration of suspended solids in the effluent fluid is determined by the flow rate of cooling water [08-12].

The results of our experiment which involved the sepa- ration of the effluent using porous partitions indicate the prospects of these materials' application.

\section{METHODS, CALCULATIONS, RESULTS}

To develop the methods of calculation of production units, there has been conducted the analysis of dependencies found in the literature $[13,14,15]$.

The precipitations contain a certain amount of liquid phase and the filtrate contains some amount of solid phase, the so-called carryover.

Filtering is characterized by quality and intensity.

The filtrate quality is assessed by: degree of purification entrainmentio $\left(\eta_{O}\right)$, entrainment ratio $K_{y}$ decontamination factor $K_{O}$.

The quality of precipitations is assessed by the content of liquid phase $(\omega)$, humidity $\left(\omega_{B J}\right)$ and impurity content $\left(C_{O}\right)$.

The intensity of filtration process is evaluated by the process rate and performance of the filtrate. The volume of filtrate $(V)$ passing through the unit of filtration area $(S)$, and being normal to the direction of motion per unit time $(t)$ is meant by the rate of filtration.

$$
\sigma=\frac{d V}{d \tau S} ; \quad \sigma_{C P}=\frac{V}{\tau S}
$$

There can be distinguished instantaneous $(\sigma)$ and average $\left(\sigma_{C P}\right)$ iltration rates:

The driving force for filtration process is pressure difference $P$ (pressure difference on both sides of filtering partitions. For incompressible precipitations filtration rate is directly proportional to differential pressure. The coefficient of proportionality depending on filtration parameters and the properties of a filtering partition and suspensions is called resistance to filtration. This resistance is related to unit of filtrate viscosity $(\mu)$. The ratio between filtration rate and pressure difference $P$ is described by Darcy's law. 


$$
\sigma_{C P}=\frac{P}{\mu R_{C P}}=\frac{P}{R_{O B}}
$$

where $R c p$ - average resistance to filtration per unit of viscosity;

Roб - total resistance to filtration.

Specific capacity of filter in relation to filtrate is the filtrate volume obtained from filtering surface unit during the entire cycle of filtration.

$$
\mathrm{Q}_{\Phi}=\frac{\mathrm{V}}{\tau_{\mathrm{u}} \mathrm{S}}=\frac{\mathrm{V}}{\left(\tau+\tau_{\mathrm{P}}+\tau_{\mathrm{BC}}\right) \mathrm{S}}
$$

where $\tau_{u}$ - the total duration of cycle;

$\tau$ the duration of filtration;

$\tau_{P}$ the duration of filtering surface regeneration;

$\tau_{B C}$ the duration of auxiliary operations.

The specific productivity of filter concerning wet precipitations $Q O C$ is determined by means of the ratio:

$$
\mathrm{Q}_{\mathrm{OC}}=\frac{\mathrm{m}_{\mathrm{OC}}}{\tau_{\mathrm{u}} \mathrm{S}}
$$

The specific productivity of filter concerning solid-phase or dry precipitations is equal to:

$$
\mathrm{Q}_{\mathrm{T}}=\frac{\mathrm{m}_{\mathrm{OC}}-\mathrm{m}_{\mathrm{B} Л}}{\tau_{\mathrm{n}} \mathrm{S}}=\frac{\mathrm{m}_{\mathrm{OC}}\left(1-\frac{\omega_{\text {ВЛ }}}{100}\right)}{\tau_{\mathrm{u}} \cdot \mathrm{S}}
$$

During the filtration process the main parameters are pressure difference and filtration rate $[14,15]$.

In practice there can be observed several different process conditions:

1. Filtration at constant pressure difference $\left(\sigma_{\text {carr }}, P_{\text {carr }}\right)$.

2. Filtration at constant rate $\left(\sigma_{\text {const }}, P_{\text {oar }}\right)$.

3. Filtration with variable process rate and pressure difference $\left(\sigma_{a x r}, P_{a x r}\right)$.

In most cases, resistance to filtration during the process continuously increases. The intensity of total resistance increase to filtration while some volume of filtrate $V^{\prime}$ is being produced is associated with this resistance by the following power dependence [13]:

$$
\frac{d R}{d V^{\prime}}=K R^{n}
$$

where $K$ is a constant characterizing the intensity of increasing the total resistance to filtration;

$V^{\prime}$ - specific volume of the filtrate;

$R$ is the total resistance to filtration being related to the unit of viscosity;

$n$ is an exponent.

This equation is called a generalized equation of filtration. The exponent " $n$ " in the generalized equation can be set within a wide range [14]. However, only at fixed values of this exponent being equal to $2 ; 1,5 ; 1 ; 0,5 ; 0$ and $-\infty$, equation (6) describes processes that can be respectively identified with the following types of filtration:

- filtration with full clogging of partitions pores;

- filtration with gradual clogging of partitions pores;

- filtration of intermediate type;

- filtration with clogging of precipitate pores;

- filtration with the formation of precipitate;

- filtration at constant resistance.

Usually the idealized physical model of filtration process with clogging of pores is considered: a porous medium is given in the form of a large number of parallel cylindrical capillaries, and depending on the type of filtration, it is assumed that either the number of capillaries, or their radius gradually decreases. Using the equation of the Hagen-Poiseuille law, we obtain ratios [14, 15] which coincide with equation (6), if the values of exponent $n$ are respectively 2 and 1.5 .

An approximate physical model of filtration with clogging of pores is given in the work by V.N. Muzhikov [15].

Filtration at constant pressure is widely used in industrial and laboratory practice. Let us consider some generalized regularities of filtration at constant pressure difference. Separating the variables, integrating the generalized equation of filtration (6) in the range of R0-R, and after several transformations we obtain [14]:

$$
R=\left[(1-n) K V^{\prime}+R_{0}^{1-n}\right]^{\frac{1}{1-n}}
$$

Here $R$ is resistance to filtration at the initial moment, i.e. the resistance of filtering partition $\beta$.

While solving equation (6), the viscosity of liquid phase and filtration pressure were not explicitly taken into account. In practice, it made it somewhat difficult to use dependencies that had been obtained from the generalized equation of filtration. The following transformations [14]

introduced two above-mentioned factors.

$$
R=\frac{P}{\mu} \cdot \frac{d \tau}{d V^{\prime}}=\frac{Q}{\mu \sigma}
$$

Inserting the value $d V^{\prime}$ from equation (8) in the generalized equation of filtration (6), we integrate it within limits of $R_{0}$ to $R$ and 0 to $V^{\prime}$.

$$
\mathrm{R}=\left[\mathrm{K} \frac{\mathrm{P}}{\mu}(2-\mathrm{n}) \tau+\mathrm{R}_{0}^{2-\mathrm{n}}\right]^{\frac{1}{2-\mathrm{n}}}
$$


The solution of equations $(07,08,09)$ allows us to derive the relation between the specific volume of filtrate and the instantaneous filtration rate which varies from

$$
\begin{aligned}
& \sigma_{0}=\frac{P}{\mu R}=\frac{P}{\mu \beta} \quad \text { to } \quad \sigma=\frac{P}{\mu R} \text { : } \\
& \sigma=\frac{P}{\mu}\left[K(1-n) V^{\prime}+\beta^{1-n}\right]^{\frac{1}{n-1}}= \\
& =\left[\sigma_{0}^{n-1}-K(n-1)\left(\frac{P}{\mu}\right)^{n-1} V^{\prime}\right]^{\frac{1}{n-1}} \\
& \text { or } \\
& \mathrm{V}=\frac{1}{\mathrm{~K}(\mathrm{n}-1)}\left(\frac{\mathrm{P}}{\mu}\right)^{1-\mathrm{n}}\left(\sigma_{0}^{\mathrm{n}-1}-\sigma^{\mathrm{n}-1}\right) \\
& \sigma=\left[\sigma_{0}^{n-2}-K(n-2)\left(\frac{P}{\mu}\right)^{n-1} \cdot \tau\right]^{\frac{1}{n-2}}= \\
& =\sigma_{0}\left[1-K(n-2)\left(\frac{P}{\mu}\right)^{n-1} \sigma_{0}^{2-n} \cdot \tau\right]^{\frac{1}{n-2}}
\end{aligned}
$$

between instantaneous filtration rate and duration

between the specific volume of filtrate and duration of filtration

$$
V^{\prime}=\frac{1}{K(1-n)}\left\{\left[K(2-n) \frac{P}{\mu} \tau+\beta^{2-n}\right]^{\frac{1-n}{2-n}}-\beta^{1-n}\right\}
$$

or

$$
\left.\mathrm{V}^{\prime}=\frac{1}{\mathrm{~K}(1-\mathrm{n})}\left(\frac{\mathrm{P}}{\mu}\right)^{1-\mathrm{n}}\left\{\left[\mathrm{K}(2-\mathrm{n})\left(\frac{\mathrm{P}}{\mu}\right)^{\mathrm{n}-1} \tau+\sigma_{0}^{\mathrm{n}-2}\right]^{\frac{1-\mathrm{n}}{2-\mathrm{n}}}-\sigma_{0}^{\mathrm{n}-1}\right\} 14\right)
$$

We obtain relationships among the characteristics of suspension $\mathrm{K}$ and partition $\beta$ and specific volume of filtrate from equations (10-14) after inserting the values of exponent $\mathrm{n}$ in them: duration and instantaneous filtration rate for those types of filtering when $n \neq 1$ and $n \neq 2$.

When filtering at constant velocity, pressure difference gradually increases (in proportion to total resistance increase) from $P o$ at the beginning of the process to $P$ in the end.

In this case, equation (8) can be presented as follows:

$$
\sigma=\frac{P}{\mu R}=\frac{P_{0}}{\mu \beta}=\text { const }
$$

After expressing resistance through filtration rate and differentiating the resulting expression, the generalized equation of filtration (6) is represented as follows:

$$
\frac{d P}{d V^{1}}=K(\mu \sigma)^{1-n} P^{n}
$$

After dividing variables and integrating the obtained equation in the limits from $\mathrm{P}_{0}$ to $\mathrm{P}$ and from 0 to $V^{\prime}$, and making simple transformations we obtain [14]:

$$
\begin{aligned}
& P=\mu \sigma\left[K(1-n) V^{\prime}+\beta^{1-n}\right]^{\frac{1}{1-n}} \\
& \left(\frac{P}{P_{o}}\right)^{1-n}=1+K(1-n) \beta^{n-1} V^{\prime}
\end{aligned}
$$

As for the other mode $V^{\prime}=\tau \sigma$, then inserting the value of specific volume of filtrate in equation (18), we obtain the generalized dependence of pressure ratio change on the time:

$$
\left(\frac{P}{P_{o}}\right)^{1-n}=1+K(1-n) \beta^{n-1} \tau \sigma
$$

In the case of filtration at constant rate, the dependencies of relative pressure difference on a specific volume of filtrate and time for various kinds of filtration can be obtained from the generalized equations (17-19) by inserting the appropriate value of the exponent or by integrating equation (16) when $n=1$.

\section{CONCLUSION}

Experimental and theoretical studies have established that purification of industrial effluents from machining sites of semiconductor materials is expediently carried out by filtration using filter elements made of porous stainless steel.

This ensures a high efficiency of wastewater treatment (95-99\%), the possibility of creating compact installations that exclude contamination of water bodies and allowing the use of recycled water and utilize the separated solid phase

For practical use, filter elements made of porous stainless steel grade FNS-5 are recommended. This material is durable, easy to regenerate. 


\section{REFERENCES}

1. Najdenko, V.V., Gubanov, L.N., Akul'shin, A.A., Petrov, P.N. (1986) Avtorskoe svidetel'stvo SSSR № 1385459 Ustanovka dlya ochistki stochnyh vod.

2. Pichugin, I.G., Tairov, YU.M. (1984) Tekhnologiya poluprovodnikovyh priborov.

3. Kurnosov, A.I. (1980) Materialy dlya poluprovodnikovyh priborov i integral'nyh mikroskhem.

4. Ovcharov i dr. (1979): Podgotovka plastin bol'shogo diametra, «Zarubezhnaya ehlektronnaya tekhnika», № 23 .

5. Ida, I. (1970): Precizionnaya obrabotka kristallov arsenida galliya: Soobshch.1, Dehnsi dzajryo, T.9, L 5, s. 125-134.

6. Ida, I. (1970): Precizionnaya obrabotka kristallov arsenida galliya: Soobshch.Z, Dehnsi dzajryo, t.9, L 7, s.129-136.

7. Kurnosov, A.I., YUdin, V.V. (1979) Tekhnologiya proizvodstva poluprovodnikovyh priborov i integral'nyh skhem.

8. Kurnosov, A.I., Yudin, V.V. (1979) Fiziko-himicheskie metody obrabotki poverhnosti poluprovodnikovyh priborovi integral'nyh mikroskhem

9. Akul'shin, A.A., Krygina, A.M. (2011): Ochistka stochnyh vod ot nerastvorimyh form mysh'yaka, Izvestiya YUgo-Zapadnogo gosudarstvennogo universiteta, chast' 2, №5, s. 116-118.
10. Akul'shin, A.A. (1994): Issledovanie sostava i metodov ochistki stochnyh vod, obrazuyushchihsya $v$ processe mekhanicheskoj obrabotki poluprovodnikovyh materialov. Tezisy dokladov yubilejnoj konferencii uchyonyh kurskogo politekhnicheskogo instituta, s. 113-114.

11. Akul'shin, A.A., Dahov, N.K. (1995): Ochistka sochnyh vod predpriyatij po proizvodstvu poluprovodnikovyh ehlementov ot soedinenij mysh'yaka. Mezhdunarodnyj EHkologicheskij Forum «Sovremennye ehkologicheskie problemy provincii, s. 5-6.

12. Akul'shin, A.A., Dahov, N.K. (2003): Metod raschyota parametrov processa fil'trovaniya promstokov cherez cilindricheskie poristye fil'truyushchie ehlementy. Materialy nauchno-prakticheskoj konferencii "Ohrana okruzhayushchej sredy i racional'noe ispol'zovanie prirodnyh resursov», CHast' 1, s.71-72.

13. Kristall, Z.B., Danilenko, N.V. (1970) Podbor i opredelenie rezhimov raboty fil'troval'nogo oborudovaniya s pomoshch'yu laboratornyh modelej.

14. Malinovskaya, 14T.ZH., Kobrinskij, N.N., Kirsanov, O.S., Rejnfart V.V (1983) Razdelenie suspenzij v himicheskoj promyshlennosti

15. Muzhikov, V.N. (1980) Fil'trovanie. Teoriya i praktika razdeleniya suspenzij. 